\title{
Creativity in Learning Environments: The Case of Two Sixth Grade Art-Rooms
}

ABSTRACT The four elements of creativity - the person, process, product, and environment - that come together for the purpose of clearly and completely defining creativity, form the structure of the research. Two sixth grade art-rooms have been chosen as the setting, as a likely place to observe creativity and sixth graders as the sample group. Observations of each child in an art-room, her/his creative process, product, and the assessment of a $1 / 20$ model of the art-room made by each student, were analyzed to form a complete picture of creativity. Results showed that the three elements of creativity (person, process, and product) were significantly different from each other. In addition, process and product occurring within the same environment were highly correlated with each other.

INTRODUCTION It is important to consider creativity as the major source in any kind of thinking, and as inseparable from life itself (DeBono, 1993). Any understanding of education and learning includes the term creativity, and thus, the learning environment should carry the necessary components to support it (Demirbas $\mathcal{E}$ Demirkan, 2000; Hasirci, 2000). The learning environment in which learning and creative activities take place, should provide students the ground on which creativity can more readily flourish (Hasirci, 2000).

Due to the complex nature of creativity, a single definition is never enough to fully grasp the concept. One can elaborate on the definitions infinitely (Albert $\mathcal{E}$ Runco, 1999; Amabile, 1983; Boden, 1990; Csikszentmihalyi, 1996; DeBono, 1993; Gardner, 1982; Guilford, 1972; Joyce, Franklin, \& Neale, 1998; Parkhurst, 1999; Sternberg $\&$ Lubart, 1999). In order to form a 
unifying approach to creativity, Rhodes (as cited in Firestien, 1993) examined several definitions, and concluded that they focused around four strands that overlap and interrelate. These four strands which were the creative person, the creative process, the creative product, and the creative environment (Brown as cited in McCann, 1998; Firestien, 1993; Feldhusen, 1995; Slabbert as cited in Gilbert $\&$ Penshaw, 1996) have to be understood in order to fully grasp and define creativity. Isaksen (as cited in Firestien, 1993) introduced the concept of the 4P's [person, process, product, press (environment)] of creativity as circles that overlap, and this approach has been a base for most research on creativity (Runco, 1994; Ward, Finke, \& Smith, 1995). These factors interact continuously, when a creative person uses a creative process to develop a product that exists in an environment (Firestien, 1993; Jones, 1993). These four tools enable one to define the concept of creativity and to see the interrelations between the different kinds of influential criteria. Different sets of criteria including motivational conditions, personality factors, environmental conditions, chance factors, and products are effective on the topic of creativity. Although there is a relative uncertainty in the essence of creativity itself (Gilbert $\mathcal{E}$ Penshaw, 1996), one may understand the concept by means of studying the influential factors and the tools which the term itself provides us.

PURPOSE OF RESEARCH
Reviewing the literature related to creativity in education shows that the subject has been studied from various points of view as evaluating the creative thinking process in education, the effects of environment on students' performance and the quality of the learning environment (Guilford, 1968; Haensly $\varepsilon$ Torrance, 1990; Lackney, 1994; Livingstone $\&$ Nelson, 1994; Moore $\mathcal{E}$ Lackney, 1994). However, in previous research on creativity, the outcomes of students have been evaluated in order to understand how students have used creative thinking in paper and pencil tests. Yet, this evaluation was not sufficient in providing a total picture of the process of creativity in education, and the parameters that affect the process. Thus, there was a need for assessments being made of creativity as a concept that is in continuous "cause and effect" relation with the learning environment (Fraser \& Wubbels, 1995, p. 118).

Research in the fields of design and creativity will serve to improve the understanding of the variables involved, and better definitions and applications can be obtained. This will enable a more precise starting point for future research. It is 
important to achieve a more holistic and comprehensive approach for future research, as it is wrong to over-simplify creativity, and the effects of the environment on it (Isaksen, Puccio, \& Treffinger, 1993).

Finally, it is significant to study people as subjects involved in activity in their environment and dealing with situations (Noschis, 1982). This study aims to stress these ideas and combine them to fill a gap in research by examining creativity and the environment together. It also aims to find out how the creativity of students in art classes may be encouraged, how these activities may be promoted, and how spatial characteristics can be used to promote user satisfaction (Hasirci, 2000).

In order to set the framework that combines these items and to be able to obtain an overall evaluation of the creativity of the students, the $4 P$ 's that define creativity were utilized in the research methods. A design-related activity, leading to threedimensional work, was designed for the students to experience, so that the effects of the environment would be combined with the creativity of each student. Since, up to this date little attention had been given to three-dimensional (such as construction and model-making), design-related work in primary schools (Barnes, 1993), this was an activity that involved the necessary conditions of this research and was interesting for the students and the teachers. The idea of making of a threedimensional model of the art-room relies on the dependence of creativity on the product (May, 1980). Asking the students to design and organize their art-rooms on a model was one of the best ways to establish the connection between the art-room environment, the product, and the students.

The sample groups in this study were selected by focused sampling as two art-classes of sixth graders. Students are the "intended recipients of instruction and other cues in the learning environment", and thus, may be "the best judge of the learning context" (Anderson \& Walberg, 1974, p. 86). There were 24 students in total with 11 in the first, and 13 in the second school (ages 10-12), on which the methods of observation and the assessment of a certain given task were tested.

The age group in which the students belong to is a stage in which they are faced with a different, more formal learning environment than their previous years, so they can clearly state the differences that they feel. There are several differences in the learning environment before and after the transition from fifth to sixth grade, and thus, the assessment of the creativity 
outcomes of the students who have just made this transition is very informative (Midgley, Eccles, \& Feldlaufer, 1991).

The ages 11-14 in boys, and 10-13 in girls are the peak periods during which creativity is most likely to be worked on and developed (Dacey, 1989). After this stage, creativity either stays at the same level or begins to diminish (Denel, 1981; Gonen \& Buluc, 1997). Sixth grade is an important age, as students begin experiencing new ways of seeing, which is reflected in their art-work. A shift of attention towards realism and involvement in information gathering with utmost care is seen in these ages. Moreover, there is a great deal of effort spent on trying to depict reality and trying to integrate emotions (Barnes, 1993). It is also the age at which two and three-dimensional objects can be fully comprehended, and thus, the shift from one dimension to the other can be made in art-work (Barnes, 1993; Zelanski \& Fisher, 1987).

However, following these years, creativity either stays at the same level or starts to diminish with the effects of the social rules and regulations. This is due to a person's becoming more and more aware of the society's rules and several other features about the environment that detracts her/him from the creativity within, as s/he grows older (Baird E Lutkus, 1982; Gardner, 1985; Gonen \& Buluc, 1997). Additionally, following this age, the students go into a stage in which they become sensitive to the qualities central to art, such as style, expressiveness, balance, and composition. Although the development of this sensitivity is a useful factor in the appreciation of art, it has the character of inhibiting creativity, as it brings upon certain rules and regulations (Gardner, 1982).

Thus, it can be stated that after a certain age, an individual's mind no longer functions in the flexible, fluent, unstructured character of an earlier age (Gardner, 1982; Hanson, 1985).

Teachers were included in the sample as they spend a great deal of time with the students observing and assessing them. Moreover, they can help to "present a balanced appraisal of the total setting" (David, 1982, p. 178), and they have the ability to point out facts that the students have forgotten, or have not been able to communicate clearly (Fraser, 1982). In order to understand and be able to compare the responses of the teachers and students, both were included in the sample group. Both points of view have to be utilized together in order to form a complete picture, as the perceived characteristics of a learning environment have been stated to have larger impact on the students' outcomes than the observed variables (Fraser $\mathcal{E}$ Wubbels, 1995; Johnson, Johnson, E Zimmerman, 1996). 
SETTING OF THE STUDY

Setting I: Erken Bosori €lementory School $(\in B)$

The research was conducted at two schools, namely, Erken Basari Elementary School (EB) and Bilkent University Preparatory School (BUPS) in Ankara, Turkey. The characteristics of the schools and families were investigated and were found to be quite similar, in that they were both private schools with certain individual characteristics, and the families of the students attending these schools were of similar socio-economic condition.

The curricula of art in both schools were not traditional, in that they learned about the principles and elements of design in their art classes, unlike most schools in Turkey. In both of the schools, art classes were carried out in different spaces than the students' regular classrooms. In most schools, the classroom is the space that is used for art facilities among other lessons, however, in these two schools, a separate space was allocated for the fine arts activities.

The first school that the research was conducted in was EB, situated in the city centrum of Ankara. The art-room in EB is a space that had previously been a porch, but had later been renovated to be an art-room. In order to include the space to the school, glass has been used to cover the roof, and the walls, which makes the space look like a greenhouse. It is a space that overlooks the garden of the school and has two doors one directly accessible from the garden and the other from the school building. The space takes in plenty of light being surrounded by windows (See Figure 1).

Although the art-room is quite small, the size has not limited its use as a very flexible space. There are 11 tables $(60 \times 90$ $\mathrm{cm}$.) in the art-room, and each table allows a maximum of four

FIGURE $1 . \quad$ Plan of EB in $1 / 100$ scale.

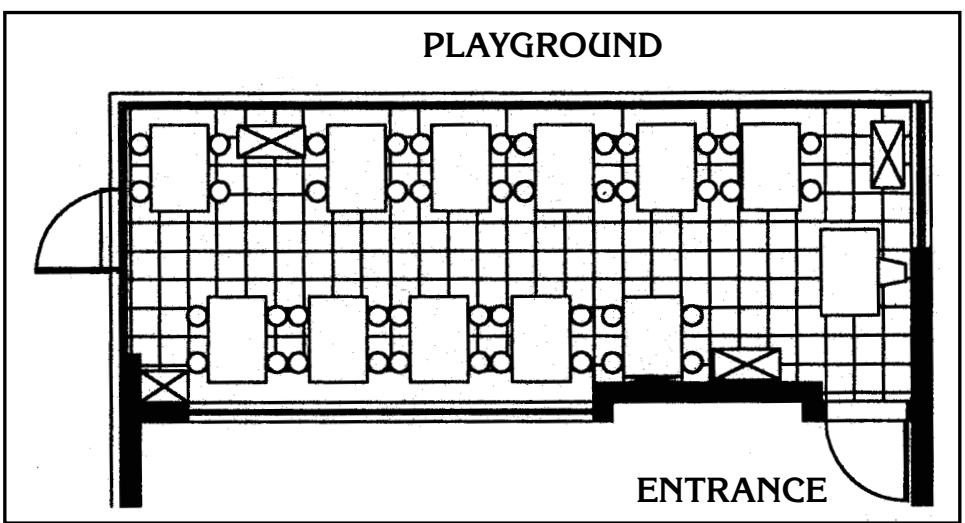


students to work. The tables are of a size permitting arrangements for both grouping and individual work. The students are allowed to move around in the space and this strengthens their relationships with the others.

The storage of material is made in individual movable units, and the display of two-dimensional art-work is made on the windows of the room, and in a central place on bulletin boards, walls, and a few tables at the entrance of the school. The problem of not being able to include fixed shelves, better storage, and displays for art-works with different characteristics arises from the size of the art-room, which has been solved by using some of the space inside the school as an extension to the room.

Setting II: The second school was BUPS, a large school on the campus of Bilkent University in Ankara. The art-room in BUPS is a space that views the playground of the school, and is connected to it with a door. The art-room is accessed by a second door that is more frequently used than the other, from inside the school. The space takes in plenty of light with the help of the large windows overlooking the playground. The organization of the space is not flexible as the location of the furniture inside the space is not changed in spite of the largeness of the space. Most of the furniture - except tables - inside the space, such as counters, shelves, and storage are fixed. There are six tables $(90 \times 180 \mathrm{~cm}$.) that are put together in groups of two to support group work. Group work and conversation are especially supported in the art-room because of one of the aims of the school is teaching English (See Figure 2).

FIGURE 2. Plan of BUPS in $1 / 100$ scale.

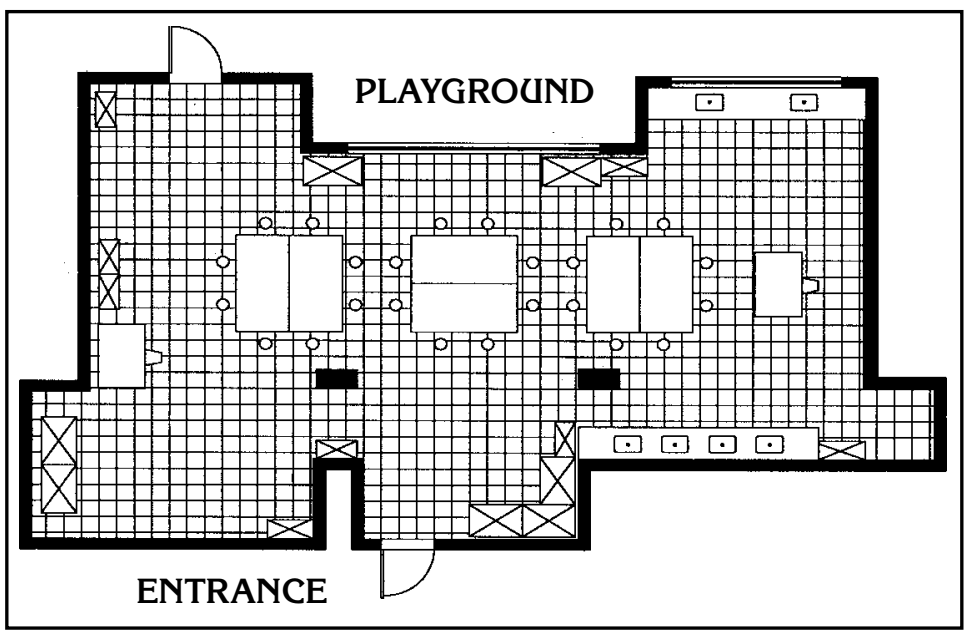


The spaciousness has advantages such as providing different areas for displays, large storage areas, and counters with sinks to keep the art-room clean. Because this room has the necessary furniture to keep the environment clean, the chances of engaging in work that involves getting dirty are higher. This is significant, as the opportunity of experiencing different activities, provides the base for creativity.

Observations and the building of $1 / 20$ models of the art-room by the students were used for assessing the creativity of the person, the process, and the product, necessary to fully grasp creativity, within the same environment. The students were given three double sessions of 40 minutes each for the whole course of the activity.

The observation method was used to evaluate the person and process through the eyes of the observer. The characteristic behavior traits of the creative and non-creative individual in general and during the process were used in the preparation of a list of binary descriptions. Each description pair was observed for each student one by one during the activity. These characteristics could mostly be observed from the students' behavior, but also they were discussed with the teacher.

The section of the list concerned with the person was composed of the following sub-headings: originality, completion, self-courage, sensitivity, negativity, isolation, control, humor. The behavioral characteristics that made up each of these headings were derived from literature and set up as oppositional phrases. Each characteristic was defined by three to six particular behavioral items (See Appendix A.1).

The section on the process was composed of the following sub-headings: originality, completion, self-courage, negativity, identification, and movement. The behavioral characteristics that made up each of these headings were derived from literature and set up as oppositional phrases. Each characteristic was defined by three to ten particular behavioral items (See Appendix A.2).

Each sub-heading was accepted to be equal in weight. The number of observed creative characteristics that belonged to the left column of the observation sheet (See Appendix A.1 and A.2) were counted for each sub-heading and the related percentages were calculated. The overall percentage was calculated for eight sub-headings for person and for seven subheadings for process. As a result, each subject had a creativity 
score related to the defined characteristics for the person and the process.

In the evaluation of the product, an existing situation was chosen, instead of a project separate from the environment. The students were asked to draw a picture of a desired artroom with reference to their current one, and use any type of drawing that best expressed their ideas. They were expressive in their drawings and depicted their needs and preferences with detail. These drawings were later used to complete any gap that may have occurred from lack of time or ability of expression in the models.

The students had to decide about how they could modify or improve their plans, and this called for a lot of creative thinking on the students' part. They had to understand and establish the balance between functional and visual elements to both create a space that was aesthetically pleasing and efficient at the same time. The two-dimensional part had the advantage of both being a base from which the three-dimensional part took off, along with the property of being a clue for the research in completing the lacking parts of the three-dimensional part.

The students were given $1 / 20$ scale frame models made of laths of their art-rooms, and asked to design (by using any kind of material of their choice, such as clay, pieces of newspaper, styrofoam, fabric, string, cardboard, colored paper, etc.) an environment that would make them happy, satisfied, and most important, creative.

In both the two-dimensional planning phase and the threedimensional model-making phase, the students were asked to decide on where they would work if they were actually using the art-room they planned. This enabled a connection between the student and the environment they designed, or identification of the student with the environment. The choice of location and activity the student preferred to be involved in, and the size of the depiction of the model of the student served to give insights to the self-concept of the student.

During the evaluation of each individual product, the previously made drawings were also taken into consideration, as they completed the individual art-rooms by providing details that could not be observed from just the model itself. Moreover, the teachers' thoughts were taken on each student's project and they were evaluated accordingly.

Design has been considered as a creative activity in various research (Goldschmidt, 1991 and 1995; Kokotovitch, 2000; 
Verstijneen and Hennesey, 1998). Designers examine design issues of creativity and the design representations as products. It is proposed in the paper that although it is difficult to measure, the ability to design is a general powerful one. Therefore, the total creativity of each product was evaluated according to three titles: the creativity of the product, the design elements, and the unifying principles. The section on the creativity of the product was composed of the following sub-headings: flexibility, fluency, novelty, originality, elaboration, ability to see deficiencies, ability to redefine, and the ability to come up with open-ended solutions. Design elements were composed of the following sub-headings: line, shape and form, space, texture, value, color, and light.

Finally, the unifying principles were composed of the following sub-headings: repetition, variety, rhythm, balance, and emphasis (Appendix B). In addition to assessing the creativity of the products, the design elements, and the unifying principles, what was aimed to be found out in this activity was to gather information on what the students think about their artrooms, and how they would have changed it if they had a chance to.

The assessment of each issue under each subtitle was done using a five-point scale (See Appendix B) according to the characteristics of the creative product, design elements, and design principles. The scores were converted to a percentage value for each sub-heading. The correlation values were calculated for each heading for the product.

Furthermore, the study examined the students' preferences and ideas about flexibility inside the learning environment and working in groups. The internal validities were controlled by Alpha Cronbach tests, and only the ones over 0.8 were taken into consideration. Two pairs from the section on the person, one from the process, and one from the product were removed as a result of these tests.

RESULTS OF THE STUDY

1. Results Related to the Person
The combination of the findings of the two methods - observations and tasks - used throughout the research, enables the understanding of the overall effect of the environment on the creativity of sixth grade students.

The person component was assessed in line with the behavioral characteristics of a creative person. A checklist was prepared according to these characteristics, and used to evaluate the characteristics of the students with regard to the qualities of a person in creative process (See Appendix A.1). 
2. Results Related to the Process
These behavioral characteristics follow as, originality, completion, self-courage, sensitivity, negativity, isolation, control, and humor. These characteristics were assessed with the help of the teachers, before the implementation of the activity. Regarding originality, the results of the two schools were quite close to each other, in that EB scored $49.99 \%$, and BUPS scored $51.28 \%$. There was a considerable difference in the completion item in which EB scored $77.27 \%$ and BUPS scored $53.84 \%$. Self-courage is an item that has also resulted in similar marks, with EB scoring higher. Concerning this item, EB scored $59.39 \%$ and BUPS scored $52.81 \%$. Negativity was again a characteristic in which EB scored higher. $36.36 \%$ was EB's score, and $27.69 \%$ was BUPS'. There was substantial difference between the two schools in the isolation item. Control was a characteristic that resulted in similar scores in the two schools, in that, EB scored $87.87 \%$, and BUPS scored $84.61 \%$. There was a large difference in humor, in that BUPS scored higher with $61.53 \%$ compared to $48.48 \%$ in EB.

The process was analyzed according to the observations that were carried out from the beginning to the end of the implementation of the task. The items to be assessed in the process observation consist of originality, self-courage, completion, negativity, identification, and movement (See Appendix A.2). Each characteristic is defined by three to ten particular behavioral items. Originality is a category consisting of characteristics such as, imitating friends, or creating new materials or tools. EB scored considerably higher than BUPS, with $74.54 \%$ compared to $54.61 \%$. This may be because the students continuously work in groups in BUPS, and thus, may be affected from each other's work. Self-courage consists of characteristics such as being independent of others in decisions, or freely and easily transferring thoughts onto the project. The students who occasionally asked questions on the structure of the project were accepted as more creative compared to the students who constantly asked the teacher and the observer about what to do, in this category. BUPS scored higher than EB, as these students were more independent about the decisions they made and responded courageously when asked about their projects, with scores of $75.52 \%$ and $68.83 \%$, respectively. Completion identifies behavior, such as being completely involved in the project, or looking around for ideas. The students who did not choose to give breaks to finish the activity, and even could not stop working when the bell rang were the ones identified as more creative for this category. 
3. Results Related to the Product (Task)
EB scored $75.76 \%$ while BUPS scored $56.16 \%$ in completion. Characteristics such as being rebellious during the process, sloppy, or capricious, not being polite, showing annoying or egocentric behavior, define negativity. Students who were indifferent to rules inside the art-room or the teachers' warnings while working, or who did not care about the mess s/he made around her/him were accepted as more creative for this category. This percentage was nevertheless quite low in both schools because of certain rules that the students had to obey in the art-room. EB scored $23.07 \%$ and BUPS quite similarly scored $20.00 \%$. Identification involves being connected to the work being done, and reflecting this with gestures while working. Without being aware of themselves, the students mimicked bodily movements of the model of themselves in their projects, and looked inside the art-room they built from different angles to feel what it would have been like to be in that room. Other students built their own models because they were told to and did not spend time trying to decide where to place the model inside the art-room. EB scored $81.81 \%$ while BUPS scored $73.07 \%$ in this category. Being flexible in bodily movements define the movement category. Students who were not working in a rigid posture, and who changed places in order to get material or cut a large piece of cardboard, for example were accepted as more creative in this category. The results in the schools were quite similar, with EB scoring $50.94 \%$ and BUPS scoring $46.16 \%$.

The assessment of the task was done according to the following factors (See Appendix B).

1. characteristics of creativity, which are flexibility, fluency, novelty, originality, elaboration, ability to see deficiencies, ability to redefine, and ability to put forward open-ended solutions.

2. design elements, which are line, shape and form, space, texture, value, color, and light.

3. unifying principles of design, which are repetition, variety, rhythm, balance, and emphasis.

The process of working, handling of materials, use of media, and critical skills are important in evaluation (Barnes, 1993), and were taken into consideration in the assessment of this project. Furthermore, the relations between what was asked of the students and what they came up with, elaboration on the theme on which they were working on, the emotions evoked by the process of the activity, the students' 
flexibility in thinking, use of materials, the effort of the students, and the total arrangement of the task, were considered.

Most students stated that they created models that they could move freely and enjoy themselves in. Three students in total especially stated that this would enable them to finish their work more quickly and be more creative. The students in EB created models that mostly consisted of different arrangements of seating allowing a choice of working space (See Figure 3). The students in BUPS preferred flexible arrangements, different seating arrangements, and comfortable furniture such as pillows, couches, and individual working areas (See Figure 4). What stood out in models of both groups was the design of different working spaces in one space, which shows the need for the flexibility of the environment allowing for changing needs. Another feature that was seen in many projects was that the number of seats in different arrangements were far more than the number of students. This may indicate the students' preference for a wide range of choices inside the artroom in order to satisfy different needs.

Breaking the three categories down, the creativity assessment part consists of flexibility, fluency, novelty, originality, elaboration, ability to see deficiencies, ability to redefine, and open-ended solutions. Although the results are alike, BUPS scored higher than EB in total, with $74.42 \%$ compared to $71.13 \%$, due especially to characteristics related to flexibility, ability to redefine, and open-ended solutions. Similarly, in the assessments of the teachers, BUPS rated higher than EB, with $74.80 \%$ to $69.80 \%$.

FIGURE 3. Student model from EB.

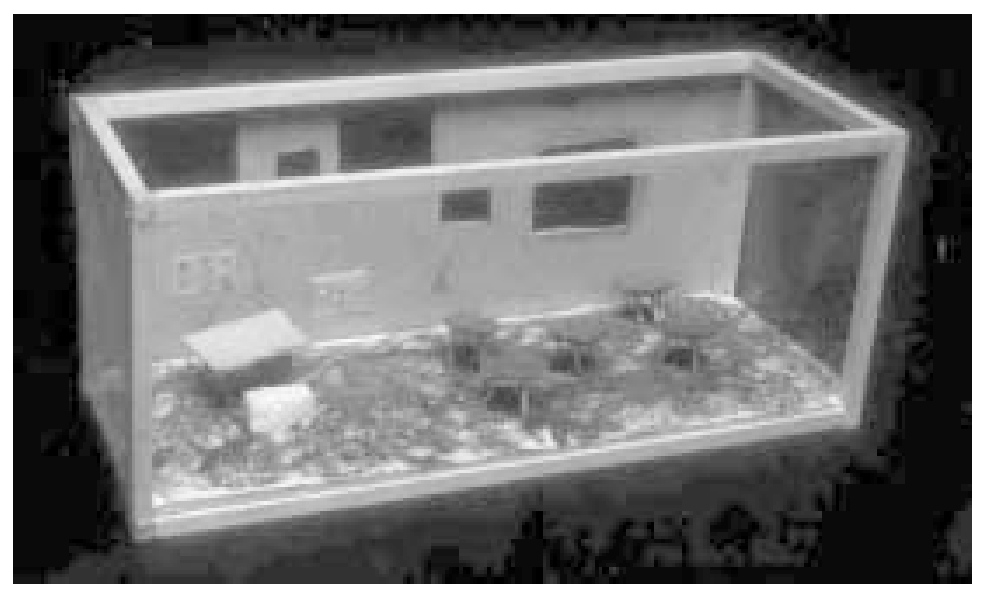


FIGURE 4. Student model from BUPS.

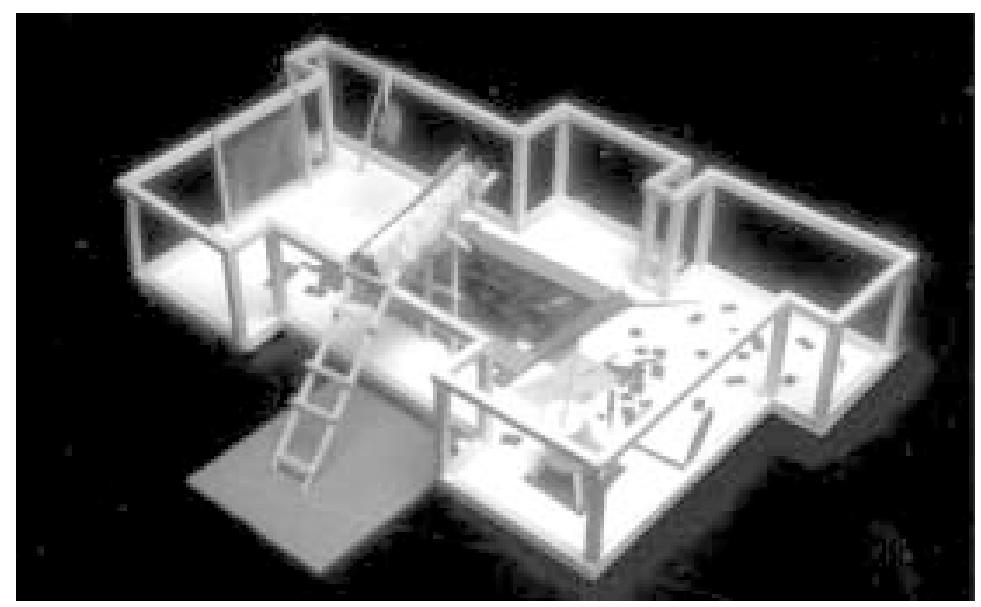

The results of the assessment of the creativity of the products, the students made in these environments, were also found to be not significantly different between the observer and the teacher in both EB $(t=1.07, d f=10, p>0.1)$ and BUPS $(t=$ $0.77, d f=12, p>0.1)$. This similarity may be a result of different characteristics standing out in both organizations. Therefore, it may be stated that certain characteristics of a flexible organization such as, ability to choose to working style; and others from a grouped organization such as, interaction between the students, have impact on the students' creativity according to this situation. The design elements part involves the usage of the line, shape and form, space, texture, value, color, and light. EB's scores were higher mostly due to color, light, and line with $70.20 \%$ in EB and $68.00 \%$ in BUPS in total. In the teachers' assessments, again EB scored slightly higher than BUPS, with $69.80 \%$ to $68.20 \%$. The unifying principles part assesses the usage of repetition, variety, rhythm, balance, and emphasis. The scores showed a slight difference here, with $70.20 \%$ in EB and $71.40 \%$ in BUPS in total. Although the results are quite similar, BUPS scored higher in variety, balance, rhythm, and emphasis; EB scored higher in repetition. It can be stated that the need for a dominating characteristic, and perhaps different seating arrangements that are spread out evenly, but not repetitive in both art-rooms is reflected in the features balance and emphasis, and stood out among other characteristics in both of the schools. In the assessments of the teachers, BUPS scored slightly higher than EB, with $71.20 \%$ compared to $70.60 \%$, in total. The assessment of the projects 
4. The Overall Results in $\in B$ and

BUPS by the observer was important in order to avoid a one-sided assessment of the projects. The results were quite consistent between the observer and the teachers, and give insight into the needs of the students in the art-room.

The mean scores of the person and process of the students in both schools were calculated one by one by taking the overall average of all of the characteristics that compose each title (See Tables 1 and 2). The mean of the product was calculated

TABL $\epsilon$ 1. Mean scores of EB students related to person, process, and product.

\begin{tabular}{cccc}
\hline Student & Person & Process & Product \\
\hline $\mathbf{1}$ & 42.70 & 26.42 & 58.49 \\
$\mathbf{2}$ & 67.08 & 68.17 & 68.16 \\
$\mathbf{3}$ & 57.08 & 69.28 & 68.28 \\
$\mathbf{4}$ & 72.49 & 75.00 & 69.11 \\
$\mathbf{5}$ & 58.33 & 61.90 & 70.66 \\
$\mathbf{6}$ & 50.41 & 65.95 & 64.46 \\
$\mathbf{7}$ & 51.04 & 44.04 & 56.31 \\
$\mathbf{8}$ & 72.08 & 68.57 & 70.17 \\
$\mathbf{9}$ & 69.37 & 68.57 & 69.73 \\
$\mathbf{1 0}$ & 66.66 & 62.85 & 63.61 \\
$\mathbf{1 1}$ & 52.29 & 67.61 & 67.75 \\
\hline
\end{tabular}

TABL $\in$ 2. Mean scores of BUPS students related to person, process, and product.

\begin{tabular}{ccrc}
\hline Student & Person & Process & Product \\
\hline $\mathbf{1}$ & 66.87 & 61.66 & 66.69 \\
$\mathbf{2}$ & 59.16 & 100.00 & 83.70 \\
$\mathbf{3}$ & 19.16 & 43.33 & 53.46 \\
$\mathbf{4}$ & 73.12 & 66.11 & 75.93 \\
$\mathbf{5}$ & 70.41 & 78.33 & 75.36 \\
$\mathbf{6}$ & 59.99 & 82.22 & 70.12 \\
$\mathbf{7}$ & 57.29 & 39.52 & 51.77 \\
$\mathbf{8}$ & 53.53 & 74.44 & 64.66 \\
$\mathbf{9}$ & 41.04 & 45.47 & 58.47 \\
$\mathbf{1 0}$ & 47.70 & 39.04 & 58.66 \\
$\mathbf{1 1}$ & 50.41 & 67.22 & 63.92 \\
$\mathbf{1 2}$ & 25.41 & 23.09 & 39.64 \\
$\mathbf{1 3}$ & 63.33 & 62.22 & 67.71 \\
\hline
\end{tabular}


by taking the average of the three sub-headings that compose this element.

The correlation between the three elements of creativity was analyzed in both schools using Minitabs.

Table 3 and 4 provide descriptive data of the correlation matrices between the three elements of creativity in EB and BUPS.

Process and product were highly correlated in BUPS and EB (correlation coefficient $=0.921 ; 0.831$, respectively). Oneway analysis of variance showed that the three elements of creativity were significantly different from each other in EB $(F=9.34, d f=2, p=0.008)$ and BUPS $(F=46.05, d f=2$, $p=0.000$ ). From this correlation (Table 3 and 4 ), it may be

TABL $\in$ 3. Correlation among three elements of creativity for EB.

\begin{tabular}{|c|c|c|c|c|c|c|}
\hline \multirow{2}{*}{\multicolumn{2}{|c|}{$\begin{array}{l}\text { Elements of } \\
\text { Creativity }\end{array}$}} & \multirow[b]{2}{*}{ Person } & \multirow[b]{2}{*}{ Process } & \multicolumn{3}{|c|}{ Product } \\
\hline & & & & Creativity & $\begin{array}{l}\text { Design } \\
\text { elements }\end{array}$ & $\begin{array}{l}\text { Unifying } \\
\text { principles }\end{array}$ \\
\hline \multicolumn{2}{|c|}{ Process } & 0.718 & & & & \\
\hline \multirow{3}{*}{ 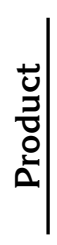 } & Creativity & 0.392 & 0.743 & & & \\
\hline & $\begin{array}{l}\text { Design } \\
\text { Elements }\end{array}$ & 0.477 & 0.214 & 0.157 & & \\
\hline & $\begin{array}{l}\text { Unifying } \\
\text { principles }\end{array}$ & 0.323 & 0.513 & 0.0 .76 & -0.136 & \\
\hline \multicolumn{2}{|c|}{ Product (Mean) } & 0.663 & 0.830 & 0.693 & 0.546 & 0.547 \\
\hline
\end{tabular}

TABL $\in$ 4. Correlation among three elements of creativity for BUPS

\begin{tabular}{|c|c|c|c|c|c|c|}
\hline \multirow{2}{*}{\multicolumn{2}{|c|}{$\begin{array}{l}\text { Elements of } \\
\text { Creativity }\end{array}$}} & \multirow[b]{2}{*}{ Person } & \multirow[b]{2}{*}{ Process } & \multicolumn{3}{|c|}{ Product } \\
\hline & & & & Creativity & $\begin{array}{l}\text { Design } \\
\text { elements }\end{array}$ & $\begin{array}{l}\text { Unifying } \\
\text { principles }\end{array}$ \\
\hline \multicolumn{2}{|c|}{ Process } & 0.637 & & & & \\
\hline \multirow{3}{*}{$\begin{array}{l}\overrightarrow{\mathrm{U}} \\
\bar{t} \\
\mathrm{D} \\
\overline{0}\end{array}$} & Creativity & 0.777 & 0.833 & & & \\
\hline & $\begin{array}{l}\text { Design } \\
\text { Elements }\end{array}$ & 0.714 & 0.905 & 0.828 & & \\
\hline & $\begin{array}{l}\text { Unifying } \\
\text { principles }\end{array}$ & 0.654 & 0.850 & 0.781 & 0.830 & \\
\hline \multicolumn{2}{|c|}{ Product (Mean) } & 0.766 & 0.921 & 0.933 & 0.944 & 0.929 \\
\hline
\end{tabular}


concluded that the elements of creativity represent a high degree of dependence across person, product and process. The correlations among the components of product showed that there was no considerable difference among them (See Table 3 and 4). Throughout the article, the ability to design and creativity are regarded as separate but possibly connected talents.

Multiple regression was used to estimate how well the students would achieve in a product design if they had certain creativity characteristics. The regression equation for EB is: Product $=46.5+0.069$ (Person) +0.251 (Process) .

Having obtained the results of the multiple regression for the analysis of EB, the following questions can be asked: How good is this estimation as a whole? or How much might the design grades (product design) for individual students vary from what is predicted? The coefficient of determination $(R-$ $s q$ ) is $70 \%$, which means that the equation explains $70 \%$ of the variation in person and product. The remaining 30\% is the percentage of variance in the scores that is left unexplained.

When BUPS is analyzed, one can see that, $R$-sq is $90.2 \%$, meaning that the equation explains $90.2 \%$ of the variation in person and product scores. The regression equation is (Product $)=28.5+0.215$ (Person) +0.399 (Process) explains $90.2 \%$ of the variation in person and product creativity. There may be several possible reasons for the unexplainable percentage in the two schools. First, we do not have results for a random sample of all students. Second, the design project may not do a very good job at measuring the students' creativity. The remaining $9.8 \%$ of the variation in sixth graders is left unexplained.

The creativity of the person and process have value in forecasting who will succeed in product creativity. In both schools, both of the coefficients for the person and process are positive. This indicates that design grade tends to increase as the creativity of the person and process increases.

DISCUSSION AND CONCLUSIONS
This study made use of the 4P's of creativity in order to find out the means by which these elements are related, in order to make use of the findings in the designing of learning environments. The twenty-four students in the two sixth grade artrooms who were chosen as the sample group gave useful information about the learning environments that they were in, and how it influenced their creativity. The schools had similar curricula and the students were coming from similar 
socio-economic backgrounds. Their age group was the same and they had similar experience in art. Therefore the results were evaluated within this context.

Wechsler (1993) had stated the importance of the creative training process for students to be more "conscious and receptive" to their environment (p. 117), in addition to the importance of factors such as the teacher's behavior in the classroom which may interfere with the creative process (Fraser, 1991; Torrance, 1970; Walberg \& Greenberg, 1997). This, in return, had beenfound to be influential on students' grades. Although a close relationship has been stated between the elements of creativity, the product in this study (models of the art-room), and its assessment taking different issues into consideration (creativity of the product, design elements, and unifying principles) may allow a more elaborate understanding of the relations in between the elements of creativity.

Bailin (1994) and Eysenck (1996) are among many that have stated that a change in one of the four elements of creativity does not necessarily bring about a change in one or more of the three remaining elements. However, this study showed that there were significant relations between them. This aspect of the study has shown similarity with findings of Besemer and O'Quin (1993), and Firestien (1993) who has stated the significant influence of the person and process on the product. Nevertheless, the introduction of a design related product and the architectural task that has been set are quite different from previous studies.

The findings of this research suggest several possibilities for future research. This research study supports the significance of the learning environment, and more specifically the art-room, on creativity. For further research, a sample group of greater size could be chosen, in order to control the findings for larger sample groups. In addition, different sample groups and different types of learning environments could be investigated for their effects.

The framework of the 4P's proved useful in a study that investigated the relationships between them. Results showed that the three elements of creativity (person, process, and product) were significantly different from each other. Also, process and product occurring within the same environment were highly correlated with each other. The creativity of the person and process can be used as parameters in determining the creativity level of the product as an output. This framework that was adapted to the study for means of operationalization 
has also enabled new opportunities for creativity research due to its unique interpretation and methodology. This aspect may broaden the scope of creativity research, in addition to giving useful feedback to the field of design.

REFERENCES ALBERT, R. S. \& RUNCO, M. A. (1999). A History of Research on Creativity. In R. J. Sternberg (Ed.) Handbook of Creativity (pp. 16-31). Cambridge: Cambridge University Press.

AMABILE, T. M. (1983). The Social Psychology of Creativity. NY: SpringerVerlag.

ANDERSON, G. J. \& WALBERG H., J. (1974). Learning Environments. In H. J. Walberg (Ed.) Evaluating Educational Performance: A Sourcebook of Methods, Instruments, and Examples (pp. 81-98). Berkeley, CA: McCutchan Publishing Company.

BAILIN, S. (1994). Achieving Extraordinary Ends: An Essay on Creativity. NJ: Ablex Publishing Corporation.

BAIRD, J. C. \& LUTKUS, A. D. (1982). From Spatial Perception to Architectural Construction. In J. C. Baird \& A. D. Lutkus (Eds.) Mind Child Architecture (pp. 3-20). Hanover, NH: University Press of New England.

BARNES, R. (1993). Art, Design and Topic Work 8-13. NY: Routledge.

BESEMER, S. P. \& O'QUIN, K. (1993). Assessing Creative Product: Progress and Potentials. In S. G. Isaksen, M. C. Murdock, R. L. Firestien, \& D. J. Treffinger (Eds.) Nurturing and Developing Creativity: The Emergence of a Discipline (pp. 331-351). Norwood, NJ: Ablex Publishing Corporation.

BODEN, M. A. (1990). The Creative Mind: Myths and Mechanisms. London: Basic Books.

CSIKSZENTMIHALYI, M. (1996). Creativity: Flow and Psychology of Discovery and Invention. NY: Harper Perennial.

DACEY, J. S. (1989). Fundamentals of Creative Thinking. NY: Lexington Books; An Imprint of Macmillan, Inc.

DAVID, T. G. (1982). Functional Dimensions of Classroom Environments. In J. C. Baird \& A. D. Lutkus (Eds.) Mind Child Architecture (pp. 174194). Hanover, NH: University Press of New England.

DEBONO, E. (1993). Serious Creativity: Using the Power of Lateral Thinking to Create New Ideas. London: Harper Collins Publishers.

DEMIRBAS, O. \& DEMIRKAN, H. (2000). Privacy dimensions: a case study in the interior architecture design studio. Journal of Environmental Psychology, 20, (1), 53-64.

DENEL, B. (1981). Temel Tasarim ve Yaraticilik. Ankara: METU Faculty of Architecture Press.

EYSENCK, H. (1996). The Measurement of Creativity. In M. A Boden (Ed.) Dimensions of Creativity (pp. 199-242). Cambridge, MA: The MIT Press.

FELDHUSEN, J. F. (1995). Creativity: a knowledge base, metacognitive skills, and personality factors. Journal of Creative Behavior, 29, (4), 255-268.

FIRESTIEN, R. L.(1993). The Power of the Product. In S. G. Isaksen, M. C. Murdock, R. L. Firestien, \& D. J. Treffinger (Eds.) Nurturing and Developing Creativity: The Emergence of a Discipline (pp. 261-277). Norwood, NJ: Ablex Publishing Corporation. 
FRASER, B. J. (1982). Development of short forms of several classroom environment scales. Journal of Educational Measurement, 19, (3), 221-227.

FRASER, B. J. (1991). Two Decades of Classroom Environment Research. In B. J. Fraser \& H. J. Walberg (Eds.) Educational Environments: Evaluation, Antecedents, and Consequences (pp. 3-28). NY: Pergamon Press.

FRASER, B. J. \& WUBBELS, T. (1995). Classroom Learning Environments. In B. J. Fraser \& H. J. Walberg (Eds.) Improving Science Education (pp. 117-144). Chicago, IL: The Univesity of Chicago Press.

GARDNER, H. (1982). Art, Mind, Brain: A Cognitive Approach to Creativity. NY: Basic Books Inc., Publishers.

GARDNER, H. (1985). Frames of Mind: The Theory of Multiple Intelligences. NY: Basic Books Inc., Publishers.

GILBERT, F. W. \& PENSHAW, P. J. (1996). A preliminary assessment of the effectiveness of creativity training in marketing. Journal of Marketing Education, 18, (3), 46.

GOLDSCHMIDT, G. (1991). The dialectics of sketching. Creativity Research Journal. 4, (2), 123-143.

GOLDSCHMIDT, G. (1995). The designer as a team of one. Design Studies, $16,(2), 189-209$.

GONEN, M. \& BULUC, N. (1997). Yaraticilik ve Ozellikleri. Ankara: Milli Egitim Bakanligi, Kiz Teknik Ogretim Genel Mudurlugu.

GUILFORD, P. J. (1968). Intelligence, Creativity, and Their Educational Implications. San Diego, CA: Robert R. Knapp Publications.

GUILFORD, P. J. (1972). Creativity: Yesterday, Today, and Tomorrow. In W. J. Gragey, P. A. Cheesebro, \& J. J. Johnson (Eds.) Learning Environments: Readings in Educational Psychology (pp. 118-128). NY: Holt, Reinhhart, Winston.

HAENSLY, P. A. E TORRANCE, E. P. (1990). Assessment of Creativity in Children and Adolescents. In C. R. Reynolds \& R. W. Kamphaus (Eds.) Handbook of Psychological and Educational Assessment of Children: Intelligence and Achievement (pp. 697-722). NY: The Guilford Press.

HANSON, H. L. (1985). Managing Creative Assets. Edina, MN: Chiefton Publishing.

HASIRCI, Deniz. (2000). The Effects of the Design and Organization of Learning Environments on Creativity: The Case of Two Sixth Grade Art-Rooms. MFA Thesis. Bilkent U.

ISAKSEN, S. G., PUCCIO, G. J., \& TREFFINGER, D. J. (1993). An ecological approach to creativity research: profiling for creative problem solving. Journal of Creative Behavior, 27, (3), 149-170.

JOHNSON, W. L., JOHNSON, A. M., \& ZIMMERMAN, K. (1996). Assessing school climate priorities: A Texas Study. The Clearing House, 70, (2), 64-66.

JONES, L. (1993). Barriers to Creativity and Their Relationship to Individual, Group, and Organizational Behavior. In S. G. Isaksen, M. C. Murdock, R. L. Firestien, \& D. J. Treffinger (Eds.) Nurturing and Developing Creativity: The Emergence of a Discipline (pp. 133-154). Norwood, NJ: Ablex Publishing Corporation.

JOYCE, M., FRANKLIN, K., \& NEALE, P. (1998). What stimulates the creative process? The Journal of Design and Technology Education 3, (2), 113-116. 
KOKOTOVICH, V. (2000). Mental synthesis and creativity in design: and experimental examination. Design Studies, 21, (5), 437-449.

LACKNEY, J. A. (1994). Educational Facilities: The Impact and Role of the Physical Environment of the School on Teaching, Learning, and Educational Outcomes. Milwaukee, Wisconsin: Publications in Architecture and Urban Planning, Center for Architecture and Urban Planning Research.

LIVINGSTONE, L. P. \& NELSON, D. L. (1994). Person-environment fit and creativity: an examination of supply-value and demand-ability versions of fit. Journal of Management, 23, (2), 119-147.

MAY, R. (1980). The Courage to Create. NY: W. W. Norton and Company, Inc.

McCANN, M. (1998) The Creativity/ IQ Interface: Old Answers and Some New

Questions. Retrieved June 23, 1998 on the World Wide Web: http:// www.Tased.edu.au/tasonline/tag/aaegt7/mccann.htm.

MIDGLEY, C., ECCLES, J. S., \& FELDLAUFER, H. (1991). Classroom Environment and the Transition to Junior High School. In B. J. Fraser $\mathcal{E}$ H. J. Walberg (Eds.) Educational Environments: Evaluation, Antecedents, and Consequences (pp. 113-139). NY: Pergamon Press.

MOORE, G. T. \& LACKNEY, J. A. (1994). Educational Facilities for the Twenty-First Century: Research Analysis and Design Patterns. Wisconsin, Milwaukee: Publications in Architecture and Urban Planning, Center for Architecture and Urban Planning Research.

NOSCHIS, K. (1982). The Child in the Laboratory: Not Just Conforming to Prompts. In J. C. Baird \& A. D. Lutkus (Eds.) Mind Child Architecture (pp. 139-158). Hanover, NH: University Press of New England.

PARKHURST, H. B. (1999). Confusion, lack of consensus, and the definition of creativity as a construct. The Journal of Creative Behavior, 33, (1), $1-21$.

RUNCO, M. (1994). Creativity and its Discontents. In M. P. Shaw \& M. A. Runco (Eds.) Creativity and Affect (pp. 102-126). Norwood, NJ:Ablex Publishing Corporation.

STERNBERG, R. J. E LUBART, T. I. (1999). The Concept of Creativity: Prospects and Paradigms. In R. J. Sternberg (Ed.). Handbook of Creativity (pp. 3-15). Cambridge: Cambridge University Press.

TORRANCE, E. P. (1970). Encouraging Creativity in the Classroom. Dubuque, IA: Wm. C. Brown Company Publishers.

VERSTIJNEN, I. M. \& HENNESSEY, J. M. (1998). Sketching and creative discovery. Design Studies, 19, (4), 519-546.

WALBERG, H. J. \& GREENBERG, R. C. (1997). Using the learning environment inventory. Educational Leadership, 54, (8), 45-46.

WARD, T. B., FINKE, R. A., \& SMITH, S. M. (1995). Creativity and the Mind: Discovering the Genius Within. NY: Plenum Press.

WECHSLER, S. (1993). Issues on Stimulating Creativity in the Schools: A South American Perspective. In S. G. Isaksen, M. C. Murdock, R. L. Firestien, E D. J. Treffinger (Eds.) Nurturing and Developing Creativity: The Emergence of a Discipline (pp. 100-130). Norwood, NJ: Ablex Publishing Corporation.

ZELANSKI, P. \& FISHER, M. P. (1987). Shaping Space. NY: Holt, Rinehart and Winston, Inc.

Deniz Hasirci and Halime Demirkan, Bilkent University, Faculty of Art, Design, and Architecture, Department of Interior Architecture and Environmental Design, 06533 Bilkent, Ankara, Turkey, Tel: ++90 312 2902643, Fax: ++90 312 2664136. E-mail: hasirci@bilkent.edu.tr, demirkan@bilkent.edu.tr 
APPENDIX A The Observation of the Students.

\section{Name:}

Age:

Sex:

School:

\section{Appendix A.1. CREATIVE PERSON}

\section{ORIGINALITY}

\section{CREATIVE - NON-CREATIVE}

$\begin{aligned} \text { unconventional } & - \text { conventional } \\ \text { having wild, silly, unusual ideas } & - \text { having down to earth, usual ideas } \\ \text { radical } & - \text { not radical } \\ \text { scrambled mind } & - \text { organized, common thinking } \\ \text { complex } & - \text { simple } \\ \text { has the ability to fashion products } & - \text { can not easily fashion products }\end{aligned}$

\section{COMPLETION}

\section{CREATIVE - NON-CREATIVE}

gets to work quickly - spends time before getting to work will work until the completion of work - will work until the completion of work energetic, enthusiastic about work - not energetic, enthusiastic about work does not mingle with others - mingles with the whole class

\section{SELF - COURAGE}

CREATIVE - NON-CREATIVE

\begin{tabular}{|c|c|}
\hline $\begin{array}{r}\text { non conforming } \\
\text { self sufficient } \\
\text { self accepting } \\
\text { egocentric } \\
\text { egotistic } \\
\text { secure } \\
\text { emotionally mature } \\
\text { able to cope with abuse } \\
\text { self-centered } \\
\text { does not ask for help } \\
\text { internally oriented } \\
\text { willing to take risks } \\
\text { adventurous } \\
\text { opeful with complex tasks } \\
\text { not bound to habits }\end{array}$ & $\begin{array}{ll}\text { - } & \text { conforming } \\
\text { - } & \text { not self sufficient } \\
\text { - } & \text { self refusing } \\
\text { - } & \text { not egocentric } \\
\text { - } & \text { not egotistic } \\
\text { - } & \text { insecure } \\
\text { - } & \text { Emotionally immature } \\
\text { - } & \text { can not cope with abuse } \\
\text { - } & \text { not self-centered } \\
\text { - } & \text { asks for help } \\
\text { - } & \text { Externally oriented } \\
- & \text { not willing to take risks } \\
\text { - } & \text { not adventurous } \\
- & \text { panics with complex tasks } \\
- & \text { is reluctant in leaving habits }\end{array}$ \\
\hline
\end{tabular}




\section{SENSITIVITY}

CREATIVE - NON-CREATIVE

\begin{tabular}{|c|c|}
\hline $\begin{array}{r}\text { socially sensitive } \\
\text { emotionally sensitive } \\
\text { perceptive } \\
\text { curious } \\
\text { intuitive }\end{array}$ & $\begin{array}{ll}\text { - } & \text { socially ignorant } \\
\text { - } & \text { emotionally ignorant } \\
\text { - } & \text { not perceptive } \\
\text { - } & \text { not curious } \\
\text { - } & \text { not intuitive }\end{array}$ \\
\hline
\end{tabular}

\section{NEGATIVITY}

CREATIVE - NON-CREATIVE

inconsiderate of others - considerate of others

oppositional - accepting

annoying - calm

offensive - Polite

not one of the best students - One of the best students

\section{ISOLATION}

$\begin{aligned} & \text { CREATIVE - NON-CREATIVE } \\ & \text { isolated }- \text { Not isolated } \\ & \text { withdrawn }- \text { Extrovert } \\ & \text { low in sociability }- \text { High in sociability } \\ & \text { estranged }- \text { Not estranged } \\ & \text { independent of judgement }- \text { Dependent on judgement } \\ & \text { uncooperative }- \text { Cooperative }\end{aligned}$

\section{CONTROL}

\section{CREATIVE - NON-CREATIVE}

\begin{tabular}{|c|c|}
\hline $\begin{array}{r}\text { non defensive } \\
\text { stable } \\
\text { controlled }\end{array}$ & $\begin{array}{ll}\text { - } & \text { defensive } \\
\text { - } & \text { unstable } \\
\text { - } & \text { not controlled }\end{array}$ \\
\hline
\end{tabular}

\section{HUMOR}

\section{CREATIVE - NON-CREATIVE}

humorous - not humorous

enjoys being child-like, playful - Is less playful

enjoys toying with, and making - Is more ignorant of the details use of the environment of the environment 


\section{Appendix A.2. CREATIVE PROCESS}

\section{ORIGINALITY}

CREATIVE - NON-CREATIVE

\begin{tabular}{|c|c|}
\hline $\begin{array}{r}\text { enjoys finding different ways of } \\
\text { solving problems } \\
\text { adopts new perspectives } \\
\text { makes good use of material at hand } \\
\text { invents new tools and media } \\
\text { not subject to group standards } \\
\text { and control } \\
\text { does not follow models and examples } \\
\text { perfects a skill by copying } \\
\text { needs to be different } \\
\text { easily defines problems }\end{array}$ & $\begin{array}{l}\text { - does not search for new perspectives } \\
\text { - does not make good use of material } \\
\text { at hand } \\
\text { - does not think of inventing new } \\
\text { tools and media } \\
\text { - } \text { subject to group standards and } \\
\text { control } \\
\text { - follows models and examples } \\
\text { - does not need to perfect skills } \\
\text { - does not need to be different } \\
\text { - can not easily define problems } \\
\text { - has common, conventional way of } \\
\text { thinking }\end{array}$ \\
\hline
\end{tabular}

\section{COMPLETION}

\section{CREATIVE - NON-CREATIVE}

engaged in task and motivated - distracted, not motivated

involves completely in the task, - is not involved in the task becomes ignorant of the environment

feels attachment toward the environment $\mathrm{s} /$ he works in diminishing interest in other people and what they may be doing does not look around for inspiration works without interruption until does not feel attachment, ignorant of the environment he works in - interested in other people and what they may be doing - looks around for ideas finalization

\section{SELF-COURAGE}

\section{CREATIVE - NON-CREATIVE}

responds constructively to new - adapts, adjusts to existing situations situations can easily transfer life experiences to symbolic or pictorial representations needs to meet challenge attempts difficult tasks independent in choices courageous in convictions open to experience

- can not easily transfer life experiences to symbolic or pictorial representations does not search for challenge does not attempt difficult tasks dependent in choices not courageous in convictions reluctant about experience 


\section{SENSITIVITY}

$$
\text { CREATIVE - NON-CREATIVE }
$$

\begin{tabular}{|c|c|}
\hline $\begin{array}{r}\text { reacts to experience more fully in } \\
\text { thought and feeling } \\
\text { asks questions on seemingly } \\
\text { insignificant parts of the experience } \\
\text { shows increasing awareness while } \\
\text { working } \\
\text { needs flexibility in the environment }\end{array}$ & $\begin{array}{l}\text { - does not react to experience fully } \\
\text { - does not ask many questions } \\
\text { - does not show increasing awareness } \\
\text { - does not need flexibility in the } \\
\text { environment }\end{array}$ \\
\hline
\end{tabular}

\section{NEGATIVITY}

\section{CREATIVE - NON-CREATIVE}

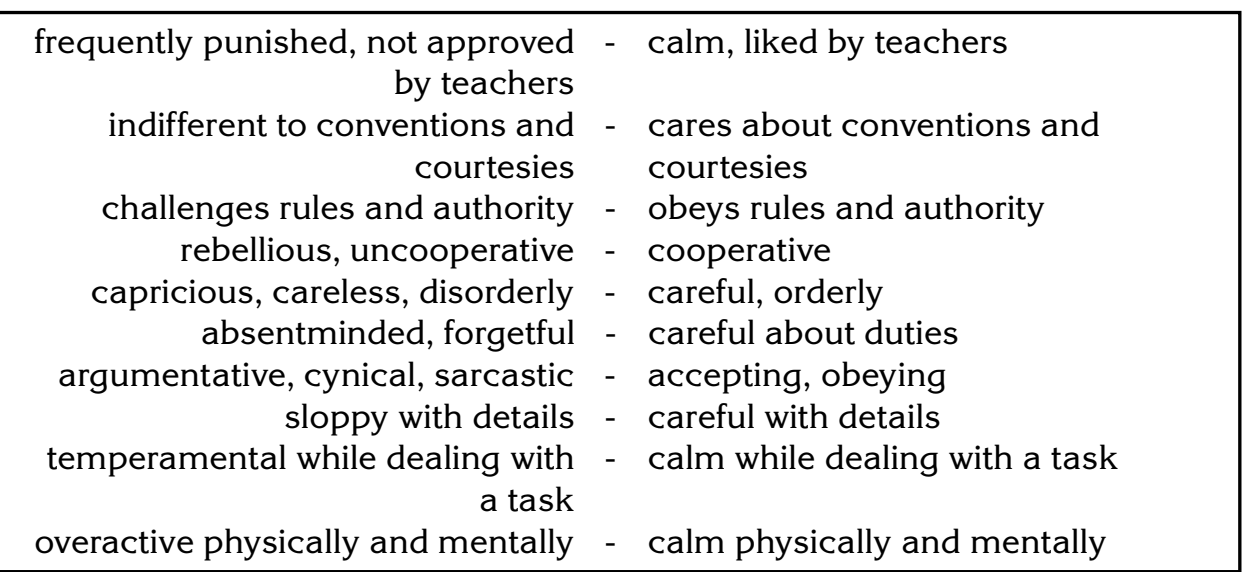

\section{IDENTIFICATION}

\section{CREATIVE - NON-CREATIVE}

identifies with task - does not identify with task

directly and/ or indirectly includes - does not include her/himself in the her/himself in work project

\section{MOVEMENT}

CREATIVE - NON-CREATIVE

\begin{tabular}{rl|} 
at ease & - nervous \\
flexible & - inflexible \\
comfortable body gestures & - rigid body gestures \\
shows kinaesthetic experiences & - does not show kinaesthetic \\
& experiences \\
likes movement while dealing & does not like movement while \\
with task & dealing with task \\
\hline
\end{tabular}


APPENDIX B Assessment of the Product.

\section{CREATIVITY ASSESSMENT}

\begin{tabular}{|c|c|c|c|c|c|}
\hline & poor & & average & & excellent \\
\hline 1. Flexibility & 1 & 2 & 3 & 4 & 5 \\
\hline 2. Fluency & $1_{--}$ & 2 & 3 & 4 & 5 \\
\hline 3. Novelty & 1 & 2 & 3 & 4 & 5 \\
\hline 4. Originality & $1_{--}$ & 2 & 3 & 4 & 5 \\
\hline 5. Elaboration & $1_{--}$ & 2 & 3 & 4 & 5 \\
\hline 6. Ability to see deficiencies & $1_{--}$ & 2 & 3 & 4 & 5 \\
\hline 7. Ability to redefine & 1 & 2 & 3 & 4 & 5 \\
\hline 8. Open-ended solutions & 1 & 2 & 3 & 4 & 5 \\
\hline
\end{tabular}

\section{ASSESSMENT OF DESIGN ELEMENTS}

1. Line $(2 D+3 D)$

\begin{tabular}{ccccc} 
poor & & average & excellent \\
\hline $1_{--}$ & $2_{--}$ & $3_{--}$ & $4_{--}$ & $5_{--}$ \\
$1_{--}$ & $2_{--}$ & $3_{--}$ & $4_{--}$ & $5_{--}$ \\
$1_{--}$ & $2_{--}$ & $3_{--}$ & $4_{--}$ & $5_{--}$ \\
$1_{--}$ & $2_{--}$ & $3_{--}$ & $4_{--}$ & $5_{--}$ \\
$1_{--}$ & $2_{--}$ & $3_{--}$ & $4_{--}$ & $5_{--}$ \\
$1_{--}$ & $2_{--}$ & $3_{--}$ & $4_{--}$ & $5_{--}$ \\
$1_{--}$ & $2_{--}$ & $3{ }_{--}$ & $4_{--}$ & $5_{--}$
\end{tabular}

\section{ASSESSMENT OF UNIFYING PRINCIPLES}

1. Repetition

2. Variety

3. Rhythm

4. Balance

5. Emphasis

\begin{tabular}{|c|c|c|c|c|}
\hline poor & & average & & excellent \\
\hline $1_{--}$ & 2 & 3 & 4 & 5 \\
\hline 1 & 2 & 3 & 4 & 5 \\
\hline 1 & 2 & 3 & 4 & 5 \\
\hline $1_{--}$ & 2 & 3 & 4 & 5 \\
\hline 1 & 2 & 3 & 4 & 5 \\
\hline
\end{tabular}

